\title{
Familial leuconychia, knuckle pads, hearing loss, and palmoplantar hyperkeratosis: an additional family with Bart-Pumphrey syndrome
}

\author{
Jeanette C Ramer, David B Vasily, Roger L Ladda
}

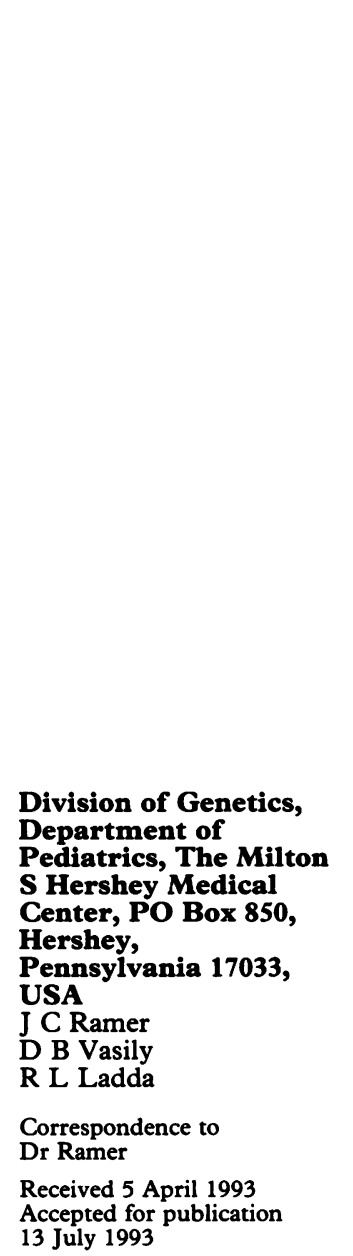

Abstract
A family with five members who have
variable findings of leuconychia, knuckle

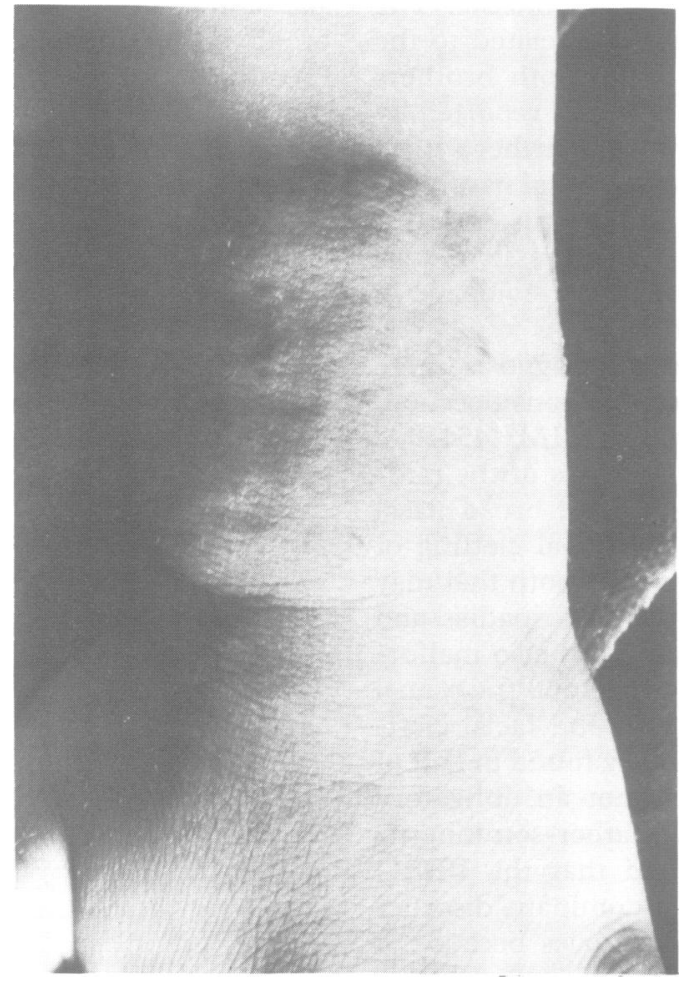

Figure 1 Dorsum of the left wrist of patient II 3 shows a raised, hyperpigmented lesion with a serpiginous border.

pads, hearing loss, and palmoplantar hyperkeratosis is described. The findings in these subjects are compared with those noted in previously reported patients with Bart-Pumphrey syndrome. The range of disorders which include knuckle pads as part of the phenotype is reviewed.

( $\mathcal{F}$ Med Genet 1994;31:68-71)

Knuckle pads are uncommon but benign skin lesions which appear as rounded, fleshy, well circumscribed papules over the dorsal surface of the small joints of the hands or feet. Although first described for a medical readership by Garrod $^{1}$ in 1904 , they were noted by artists during the Renaissance who incorporated them into portraits and sculptures along with facial likenesses of their subjects. ${ }^{2}$ In most subjects, these cutaneous growths appear in childhood then enlarge slowly over time. They can occur in multiple family members and, in this situation, appear to follow an autosomal dominant mode of transmission. ${ }^{13}$ Knuckle pads can be associated with Dupuytren's contracture but are most commonly found as an isolated anomaly, almost exclusively on the hands with feet rarely involved.

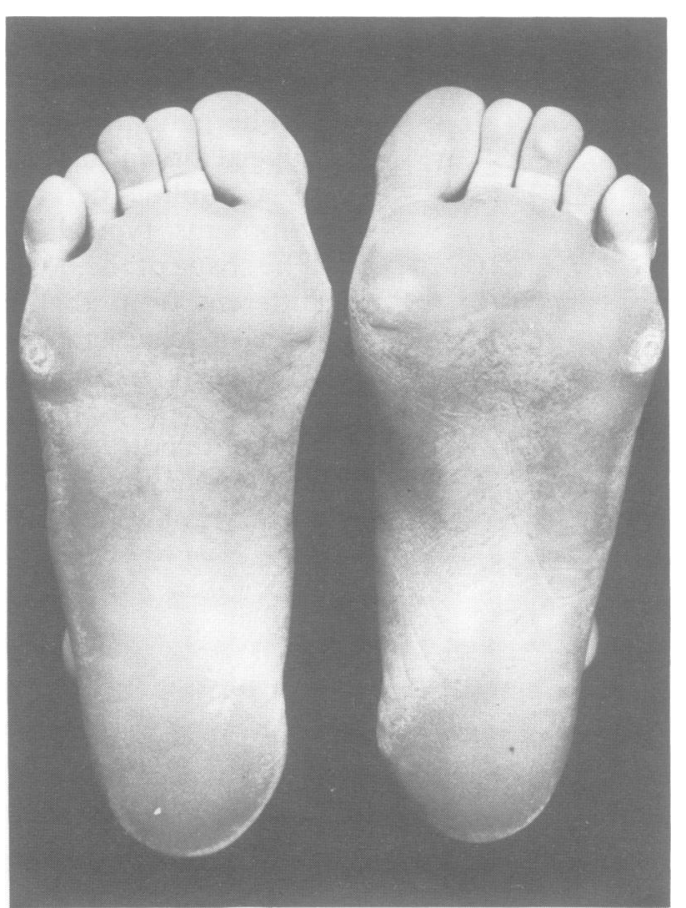

Figure 3 Soles of both feet of patient II.3 showing diffuse skin thickening as well as discrete areas of more marked hyperkeratosis.

Figure 2 Palms of patient II. 3 showing thickening and accentuation of skin creases and markings. 
In 1967, Bart and Pumphrey ${ }^{4}$ reported a six generation family in which knuckle pads were present along with congenital deafness and leuconychia. Keratoderma was also apparent in some family members. Autosomal dominant inheritance was evident in this kindred. Similarities between these patients and a child who had been reported by Schwann ${ }^{5}$ in 1963 were evident to Bart and Pumphrey. ${ }^{4}$ This child had leuconychia, sensorineural deafness, knuckle pads, and keratoderma of the palms and soles, but was the only member of his family to manifest all of these findings. Syndactyly was present in several of the other 69 members of this kindred. A third family with the same constellation of findings was described by Crosby and Vidurrizaga ${ }^{6}$ in 1976 . Four subjects in two generations were affected with knuckle pads, primarily on the toes, variable leuconychia, moderate to severe sensorineural hearing loss, and keratoderma of the soles and palms. Again the pattern of transmission was

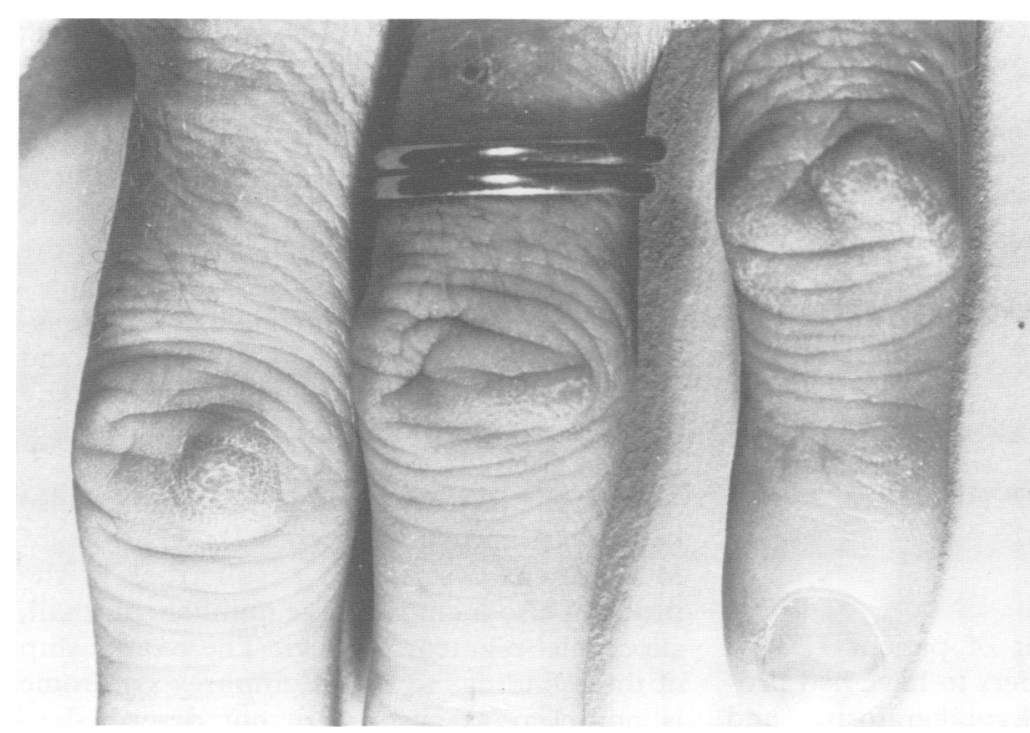

Figure 4 Left hand of patient II·3 showing diffuse thickening of the skin of the knuckles and discrete knuckle pads; note leuconychia and absent lunula of the nail of the fifth finger.

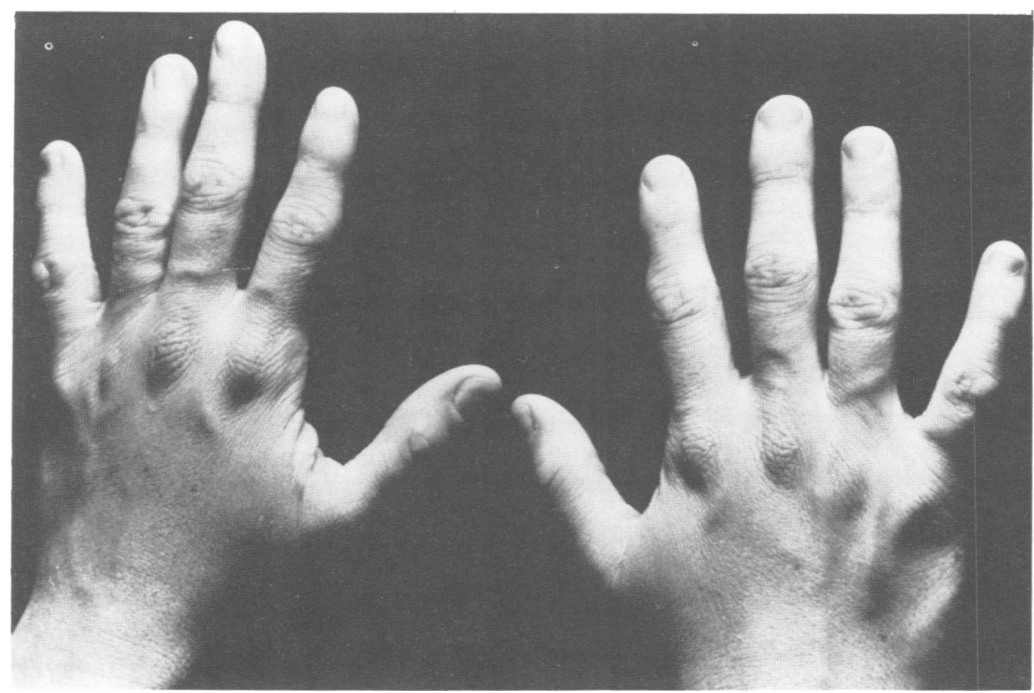

Figure 5 View of both hands of patient II.3 showing multiple knuckle pads and normal nail shape, size, and texture. consistent with autosomal dominant inheritance.

In this report, we describe a three generation family with four members who have skin abnormalities and deafness as well as one member with hearing loss only. Breast cysts and cyst-like skin lesions were present in the proband and her affected mother, findings which may represent an additional manifestation of Bart-Pumphrey syndrome.

\section{Case reports}

\section{PATIENT II $\cdot 3$}

This 24 year old white female was evaluated at the request of her dermatologist who had noted marked hyperkeratosis of the palms and soles, especially evident along the skin creases, knuckle pads involving the dorsal aspects of the proximal interphalangeal joints of both hands, mild leuconychia, and severe sensorineural deafness. Painful cysts of the breasts, axillae, and dorsum of the right forearm had developed over the previous year. She recalled that the knuckle pads had become apparent at the age of 8 years and had enlarged slowly since that time. The hearing loss was congenital and, apparently, unchanging. Hyperkeratosis had its onset in early adolescence with slow progression especially apparent on the soles of the feet.

Examination showed normal hair and teeth. Skin texture was normal except for the hands and feet. There were multiple, darkly pigmented macules and papules from 2 to $8 \mathrm{~mm}$ in diameter scattered over the upper chest, between the breasts, and in both axillae. There were a few scattered fleshy papules over the lower abdomen. Breast examination disclosed multiple tender cystic regions bilaterally. There was a discrete, raised, slightly hyperpigmented lesion on the dorsum of the left wrist which measured $2 \times 2.5 \mathrm{~cm}$. Palpation suggested that it was fluid filled (fig 1).

The palms and soles were hyperkeratotic with accentuation of crease patterns and yellow discoloration (figs 2 and 3). Knuckle pads measuring approximately 0.75 to $1 \mathrm{~cm}$ in diameter were present over the dorsal aspect of the proximal interphalangeal joints of all digits of the left hand as well as the thumb, first, and fifth fingers of the right hand (figs 4 and 5). Knuckle pads were not present on the feet. Mild leuconychia was present and lunulae were absent or poorly defined while nail shape and size were normal.

Severe sensorineural hearing loss was evident but an audiogram was not performed. The patient communicated using signing.

\section{PATIENT III $\cdot 2$}

This 2 year old male is the son of patient II 3 . He had significant hearing loss in infancy. Examination showed hyperkeratosis of the palms, especially evident over the thenar eminence and between the thumb and first finger. There were no nail changes or knuckle pads. The feet were normal. 


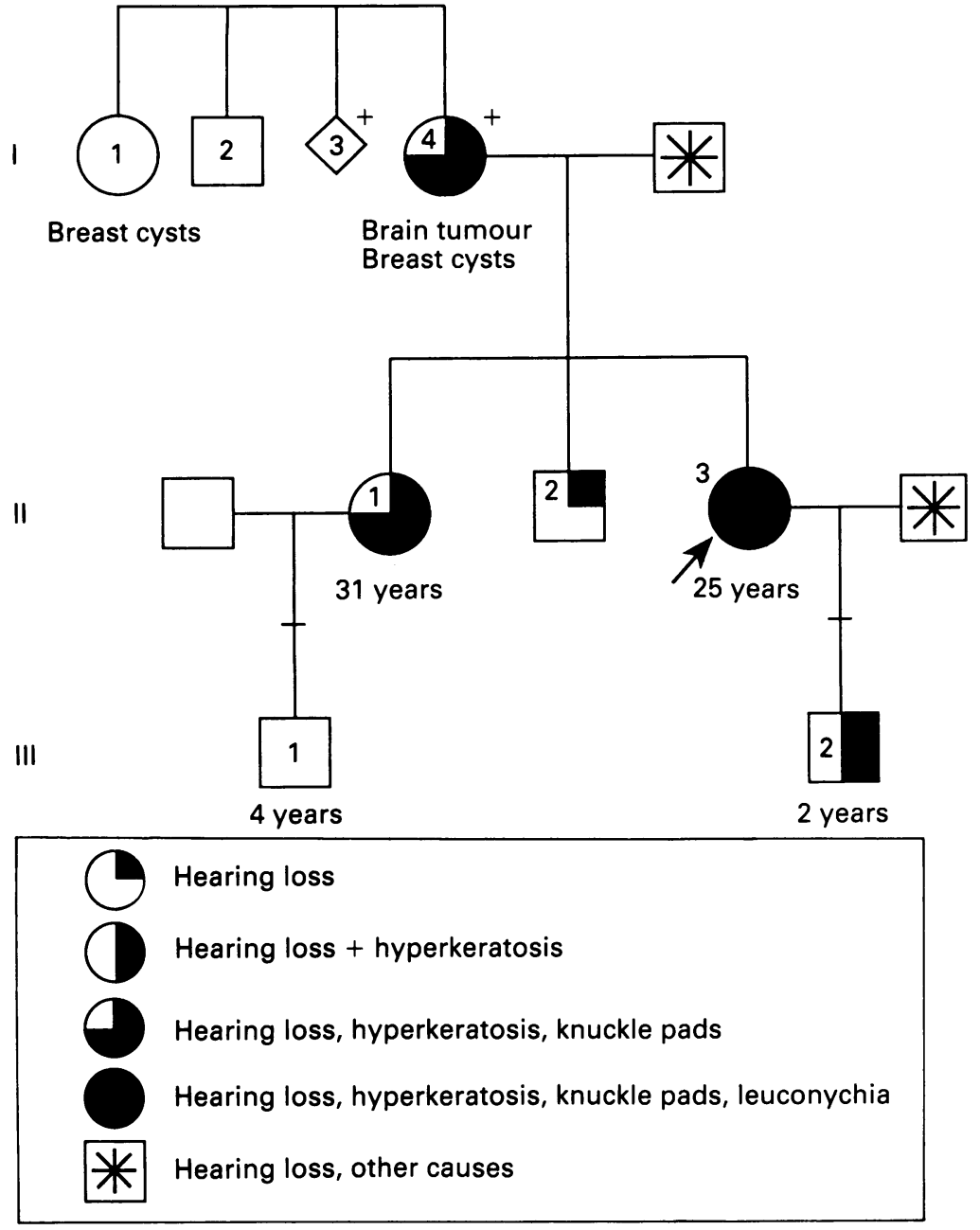

Figure 6 Family pedigree showing apparent autosomal dominant pattern of inheritance with variable expressivity.

\section{PATIENT I 4}

This patient, the mother of patient II.3, is reported by family members to have had profound hearing loss, hyperkeratosis, and knuckle pads. Leuconychia was not recalled. She was diagnosed as having breast and axillary cysts as well as a growth on the palmar surface of one wrist similar to that seen in her daughter. She had died of the effects of a brain tumour at the age of 58 years.

\section{PATIENT II $\cdot$}

This 31 year old woman was not available to be examined, but she was reported to have strik-

Table 1 Characteristics of patients with Bart-Pumphrey syndrome

\begin{tabular}{|c|c|c|c|c|c|c|}
\hline & \multicolumn{2}{|c|}{ Previously reported subjects ${ }^{3-6}$} & \multicolumn{2}{|c|}{ Current family } & \multicolumn{2}{|l|}{ Total } \\
\hline & Males & Females & Males & Females & Males & Females \\
\hline & 5 & 5 & $2^{*}$ & 3 & 7 & 8 \\
\hline \multirow{2}{*}{\multicolumn{7}{|c|}{$\begin{array}{l}\text { Leuconychia } \\
\text { Knuckle pads }\end{array}$}} \\
\hline & & & & & & \\
\hline Hands & 3 & 3 & & 2 & 3 & 5 \\
\hline \multirow{2}{*}{\multicolumn{7}{|c|}{ Hyperkeratosis }} \\
\hline & & & & & & \\
\hline Hands & 3 & 3 & 1 & 2 & 3 & 5 \\
\hline Feet & 3 & 2 & & 2 & 3 & 4 \\
\hline \multicolumn{7}{|l|}{ Hearing loss } \\
\hline Mild-moderate & 4 & 1 & 1 & & 5 & 1 \\
\hline Severe & 1 & $4 \dagger$ & 1 & 3 & 2 & 7 \\
\hline
\end{tabular}

* One patient is only 2 years of age

†Two patients had mixed conductive and sensorineural hearing loss. ing leuconychia, moderate hearing loss, and rough texture of the palms and soles along with knuckle pads. No further details were available.

PATIENT II $\cdot 2$

Moderate hearing loss was the only finding in this subject at the age of 27 years.

The family pedigree is shown in fig 6; autosomal dominant inheritance is suggested.

\section{Discussion}

The family we describe had several members with leuconychia, knuckle pads, hyperkeratosis, and hearing loss. This represents the third kindred reported to have these findings. ${ }^{4-6}$ As in the other families, an autosomal dominant mode of transmission is suggested but variability in expression is evident. As is apparent from table 1, males and females show similar findings except for the degree of hearing loss. Although the numbers of subjects evaluated is small, the majority of males have had mild to moderate hearing loss $(5 / 7)$, while females tended to have severe deafness $(7 / 8)$. The type of hearing loss is generally sensorineural but mixed sensorineural and conductive loss was evident in two patients reported by Bart and Pumphrey. One of these had dysplasia of the middle ear structures evident at surgical exploration. ${ }^{4}$ Unfortunately, detailed hearing assessment was not available for our patients and interpretation of information is complicated by the presence of isolated hearing loss in spouses in generations II and III.

Several affected women in this kindred also had breast and subcutaneous lesions thought to represent cysts. Skin peculiarities in the proband also included large numbers of small, superficial pigmented naevi. The relationship of these findings to Bart-Pumphrey syndrome is not clear as cysts were not described in previous families with this disorder. Breast cysts are common and are often evident in several family members. They could easily represent a coincidental association. Finally, an unusual subcutaneous wrist lesion with a consistency similar to that of the knuckle pads was present in two affected family members, and could represent an additional manifestation of Bart-Pumphrey syndrome.

Knuckle pads are usually an isolated, sporadic finding in an otherwise normal subject but they have also occurred as a familial trait transmitted in an autosomal dominant fashion. They can also be noted in association with other dermatological pecularities, as listed in table 2 . The majority of the disorders are rare and it is unclear if all are distinct entities. The known range of expression often rests on the description of one or two families.

Histological examination of tissue from the pads shows two distinct subtypes as noted by Paller and Hebert. $^{3}$ In the first subtype, changes are primarily evident in the epidermis and consist of thickening of the keratin layer with minimally increased fibroblasts in the upper dermis. This pattern is most common in 
Table 2 Disorders associated with knuckle pads

\begin{tabular}{|c|c|c|c|c|c|}
\hline & $\begin{array}{l}\text { Isolated knuckle } \\
\text { pads }^{23}\end{array}$ & $\begin{array}{l}\text { Dupuytren's contracture } \\
\text { and knuckle pads }{ }^{37}\end{array}$ & $\begin{array}{l}\text { Palmoplantar keratoderma } \\
\text { and knuckle pads }\end{array}$ & $\begin{array}{l}\text { Bart-Pumphrey } \\
\text { syndrome }\end{array}$ & Touraine's polyfibromatosis ${ }^{89}$ \\
\hline $\begin{array}{l}\text { Mode of inheritance } \\
\text { Age at onset } \\
\text { Location of knuckle pads }\end{array}$ & $\begin{array}{l}\text { Sporadic, some AD } \\
\text { Late childhood }\end{array}$ & $\begin{array}{l}\text { Usually sporadic, some AD } \\
\text { Adulthood }\end{array}$ & $\begin{array}{l}\text { AD } \\
\text { Late childhood }\end{array}$ & $\begin{array}{l}\mathrm{AD} \\
\text { Early childhood }\end{array}$ & $\begin{array}{l}\text { Usually sporadic, some AD } \\
\text { Older adult }\end{array}$ \\
\hline Hands & + & + & + & + & + \\
\hline Feet & $+1-$ & - & $+1-$ & + & - \\
\hline $\begin{array}{l}\text { Associated findings } \\
\text { Hyperkeratosis }\end{array}$ & - & - & + & + & - \\
\hline Ichthyosis vulgaris & _- & - & + & _- & _ \\
\hline Hearing loss & - & - & - & + & - \\
\hline Nail changes & - & - & - & + & - \\
\hline Fibromas in other regions & - & - & & - & + \\
\hline Other & None & Contractures of fingers & Eczema & - & $\begin{array}{l}\text { Dupuytren's contracture, } \\
\text { Peyronic disease, nasal polyps }\end{array}$ \\
\hline Histological findings & $\begin{array}{l}\text { Thickened keratin layer } \\
\text { and lower epidermis, } \\
\text { mildly increased fibro- } \\
\text { blasts in upper dermis }\end{array}$ & $\begin{array}{l}\text { Increased fibrous tissue } \\
\text { hypercellularity of } \\
\text { connective tissue }\end{array}$ & $\begin{array}{l}\text { Hypertrophy of stratum } \\
\text { corneum, increased number } \\
\text { of granular cell layers, } \\
\text { thickened epidermis }\end{array}$ & NR & $\begin{array}{l}\text { Hyperplasia of } \\
\text { connective tissue, } \\
\text { decreased elastic fibres }\end{array}$ \\
\hline
\end{tabular}

$\mathrm{AD}=$ autosomal dominant; $\mathrm{NR}=$ not reported.

isolated knuckle pads and in palmoplantar keratoderma with knuckle pads. The second subtype, most usually found in subjects with Dupuytren's contracture or Touraine syndrome, shows thickening and hyperplasia of collagen bundles in the dermis in addition to epidermal changes. The histological findings of the knuckle pads noted in Bart-Pumphrey syndrome have not been reported.

No candidate genetic loci have been elucidated for any of these disorders. With the exception of Bart-Pumphrey syndrome, all involve focal overgrowth of ectodermal structures. The reported disruption of middle ear bone formation in one subject and a mixed conductive and sensorineural hearing loss in several other patients suggests mesodermal involvement in Bart-Pumphrey syndrome. ${ }^{4}$ Additional detailed information regarding type and degree of hearing impairment in these subjects is needed to confirm a consistent con- ductive component, as this was noted in only one family. Unfortunately, the family we report was unwilling to undergo additional quantitation of hearing or further evaluation of skin lesions.

1 Garrod AE. Concerning pads upon the finger joints and their clinical relationships. BMF 1904;ii:8.

2 Allison JR Jr, Allison JR Sr. Knuckle pads. Arch Dermatol 1966;93:311-16.

3 Paller AS, Hebert AA. Knuckle pads in children. Am $\mathcal{J}$ Dis Child 1986;140:915-17.

4 Bart RS, Pumphrey RE. Knuckle pads, leukonychia and deafness. $N$ Engl $₹$ Med 1967;276:202-7.

5 Schwann VJ. Keratosis palmaris et plantaris cum surditate congenita et leuconychia totali unguium. Dermatologica 1963;126:335-53.

6 Crosby EF, Vidurrizaga RH. Knuckle pads, leukonychia, deafness, and keratosis palmoplantaris: report of a family. fohns Hopkins Med f 1976;139:90-2.

7 Skoog T. Dupuytren's contraction with special references to aetiology and improved surgical treatment: its occurrence 1948;96(suppl 139):1-190.

8 Young ID, Fortt RW. Familial fibromatosis. Clin Genet 1981;20:211-16.

9 Butterworth T, Ladda RL. Clinical genodermatology. New York: Praeger, 1981:196-7. 